\title{
Two new Pandanus frogs (Guibemantis: Mantellidae: Anura) from northern Madagascar
}

\author{
Richard M. LEHTINEN ${ }^{1, *}$, Frank GLAW ${ }^{2}$, Miguel VENCES ${ }^{3}$, \\ Andolalao RAKOTOARISON ${ }^{4} \&$ Mark D. SCHERZ $^{5}$ \\ ${ }^{1}$ The College of Wooster, Department of Biology, 931 College Mall, Wooster, Ohio, 44691 USA. \\ ${ }^{2,5}$ Zoologische Staatssammlung München (ZSM-SNSB), Münchhausenstr. 21, \\ 81247 München, Germany. \\ ${ }^{3,5}$ Zoological Institute, Technical University of Braunschweig, Mendelssohnstr. 4, \\ 38106 Braunschweig, Germany. \\ ${ }^{4}$ Mention Zoologie et Biodiversité Animale, Université d'Antananarivo, BP 566, \\ Antananarivo 101, Madagascar. \\ *Corresponding author: rlehtinen@wooster.edu \\ ${ }^{2}$ Email: glaw@snsb.de \\ 32Email: m.vences@tu-braunschweig.de \\ ${ }^{4}$ Email: andomailaka@gmail.com \\ ${ }^{5}$ Email: mark.scherz@gmail.com \\ ${ }^{1}$ urn:lsid:zoobank.org:author:9FCBFB1E-4A52-4747-A212-D6B9513453AC \\ ${ }^{2}$ urn:1sid:zoobank.org:author:764DC666-B65D-40C1-BE19-0F5A7294E452 \\ ${ }^{3}$ urn:1sid:zoobank.org:author:23B8FF04-06AA-43C8-A459-E0FB3BB289F6 \\ ${ }^{4}$ urn:Isid:zoobank.org:author:A354F4A8-FDD9-4072-9C27-DC17B6ED3664 \\ ${ }^{5}$ urn:lsid:zoobank.org:author:DDE9BA71-9261-483D-AC69-6985F388DD04
}

\begin{abstract}
We describe two new frog species of the genus Guibemantis Dubois, 1992 (Mantellidae) from northern Madagascar. Both species are placed in the subgenus Pandanusicola Glaw \& Vences, 1994 and, like most of their relatives, appear to only inhabit the leaf axils of Pandanus plants. Guibemantis albomaculatus sp. nov. is distinguished from other closely related species by light colored dorsolateral stripes and abundant small white spots found on its flanks and limbs. Guibemantis woosteri sp. nov. also has light-colored dorsolateral stripes and small white spots, but differs by having strongly banded forelimbs and a reddish coloration around the eye orbits. Mitochondrial DNA sequences corroborate the identity of these two new species, which appear to be regional endemics in northern and north-eastern Madagascar, respectively. These descriptions bring the species count in Pandanusicola to thirteen.
\end{abstract}

Keywords. Amphibia, Pandanusicola, new species, taxonomy, Madagascar

Lehtinen R.M., Glaw F., Vences M., Rakotoarison A. \& Scherz M.D. 2018. Two new Pandanus frogs (Guibemantis: Mantellidae: Anura) from northern Madagascar. European Journal of Taxonomy 451: 1-20.

https://doi.org/10.5852/ejt.2018.451 


\section{Introduction}

Madagascar has long been known as a center of species richness and endemicity, and no group better exemplifies this than amphibians. The island has 350 currently described species of frogs (AmphibiaWeb 2018), except for two introduced species [Hoplobatrachus tigerinus (Daudin, 1802) and Duttaphrynus melanostictus (Schneider, 1799)] and one other species also occurring on the Mascarenes and Seychelles [Ptychadena mascareniensis (Duméril \& Bibron, 1841)], all of these are endemic to the island (Glaw \& Vences 2007; Andreone 2014). In addition, numerous genetically divergent lineages have already been identified as candidate species awaiting taxonomic revision (Vieites et al. 2009; Perl et al. 2014), and despite decades of taxonomic work, new species are still being regularly described.

One example of a taxonomically long neglected group with a high proportion of undescribed diversity is the subgenus Pandanusicola Glaw \& Vences, 1994 of the genus Guibemantis Dubois, 1992 (Mantellidae). These small frogs are inhabitants of the water-filled leaf axils of Pandanus plants (except for two pond-breeding species G. liber (Peracca, 1893) and G. tasifotsy Lehtinen, Glaw, Andreone, Pabijan \& Vences, 2012), are often drably colored and have inconspicuous advertisement calls. As with many other amphibians in Madagascar and in other tropical regions, molecular analyses have suggested the presence of taxonomically undescribed but genetically well-differentiated lineages (Lehtinen et al. 2007; Vieites et al. 2009). Presently, there are eleven species in this subgenus, four of which have been described or resurrected recently (Lehtinen et al. 2011, 2012; Vences et al. 2013; Bletz et al. 2018). Most of these species were from south-eastern or central-eastern Madagascar, whereas many of the unstudied new lineages of Pandanusicola come from localities in the northern portion of the island, an area of high environmental heterogeneity and high degrees of local endemism in many groups of amphibians and reptiles (e.g., Brown et al. 2016). Herein, we describe two additional new species of Pandanusicola which apparently are restricted to northern Madagascar.

\section{Material and methods}

\section{Morphological measurements}

The following morphological measurements were taken with digital calipers to the nearest $0.1 \mathrm{~mm}$ :

ED $=$ horizontal eye diameter
END $=$ eye-nostril distance
FGL $=$ femoral gland length (in males only)
FGW $=$ femoral gland width (in males only)
FL $=$ femur length
FOL $=$ foot length
HAL $=$ hand length
HL $=$ head length
HW $=$ head width
IND $=$ internarial distance
IOD $=$ interorbital distance
LAL $=$ lower arm or forearm length
NSD $=$ nostril-snout tip distance
SVL $=$ snout-vent length
TD $=$ horizontal tympanum diameter
TL $=$ tibia length
W3FD $=$ maximum width of the third finger disc
W4FD $=$ maximum width of the fourth toe disc


When mean values are presented, they are followed by the standard deviation (SD). Abbreviations and definitions of morphological features follow Vences \& Glaw (2005), except where noted above. We also examined all specimens for the presence, position and/or shape of the inner and outer metatarsal tubercles, subarticular tubercles, lateral metatarsalia, canthus rostralis, tongue, vomerine teeth, and the supratympanic fold. Finger and toe webbing was quantified following Blommers-Schlösser (1979). Femoral gland terminology follows Glaw et al. (2000). Overall dorsal and ventral coloration and skin texture were also assessed in detail for each specimen.

\section{Institutional abbreviations}

\begin{tabular}{|c|c|c|}
\hline MNHN & $=$ & Muséum national d'Histoire naturelle, Paris, France \\
\hline UADBA & $=$ & $\begin{array}{l}\text { Université d'Antananarivo, Département de Biologie Animale (currently Mention } \\
\text { Zoologie et Biodiversité Animale, Faculté des Sciences, Université d'Antananarivo), } \\
\text { Antananarivo, Madagascar }\end{array}$ \\
\hline UMMZ & $=$ & University of Michigan, Museum of Zoology, Ann Arbor, USA \\
\hline ZFMK & $=$ & Zoologisches Forschungsmuseum Alexander Koenig, Bonn, Germany \\
\hline ZMA & $=$ & $\begin{array}{l}\text { Zoölogisch Museum Amsterdam (transferred to Naturalis Biodiversity Center in } \\
\text { Leiden), Netherlands }\end{array}$ \\
\hline ZSM & $=$ & Zoologische Staatssammlung München, Germany \\
\hline
\end{tabular}

FGMV, FGZC and ZCMV refer to F. Glaw and M. Vences field numbers.

\section{Laboratory and phylogenetic reconstruction methods}

We used standard salt extraction (Bruford et al. 1992) to extract genomic DNA from muscle tissue samples preserved in $99 \%$ ethanol and sequenced a segment of the 16S rRNA gene using primers and protocols as in Vences et al. (2013). PCR products were cleaned with enzymatic purification: incubation with 0.15 units of Shrimp Alkaline Phosphatase (SAP) and 1 unit of Exonuclease I (New England Biolabs) for $15 \mathrm{~min}$ at $37^{\circ} \mathrm{C}$ followed by $15 \mathrm{~min}$ at $80^{\circ} \mathrm{C}$. Purified PCR products were sequenced on an automated DNA sequencer (Applied Biosystems, ABI 3130XL). Sequencing reactions (10 $\mu$ l) contained 0.2 or $0.3 \mu 1$ of PCR product, $0.5 \mu \mathrm{l}$ of BigDye 3.1 (Applied Biosystems) and $0.3 \mu \mathrm{mol}$ of primer. Sequences were checked and edited in the software CodonCode Aligner 3.7.1 (CodonCode Corporation, Dedham, MA, USA). Newly determined sequences were submitted to GenBank (accession numbers MH279456-MH279469).

We aligned sequences to those from previous studies (representing all valid species of Guibemantis) in MEGA, version 7 (Kumar et al. 2016). Pairwise genetic distances were calculated with the same software. We determined the best-fitting substitution model $(\mathrm{SYM}+\mathrm{I}+\mathrm{G})$ by the Bayesian Information Criterion in jModelTest 2.1.4 (Darriba et al. 2012). We computed a phylogenetic tree by Bayesian inference with MrBayes 3.2 (Ronquist et al. 2012). Results of two independent runs of 50 million generations, each comprising four Markov Chains (three heated and one cold), were sampled every 10000 generations. Chain mixing and stationarity was assessed by examining the standard deviation of split frequencies and by plotting the $-\operatorname{lnL}$ per generation using Tracer 1.5 software (Rambaut \& Drummond 2007). Results were combined to obtain a $50 \%$-majority rule consensus tree and the respective posterior probabilities of nodes, after discarding $25 \%$ of the generations as burn-in (all compatible nodes with probabilities $<0.5 \mathrm{kept}$ ). In addition, we computed a Maximum Likelihood tree with a simpler substitution model (Kimura-2-Parameter) in MEGA 7 to avoid possible over-parametrization, and tested robustness of nodes with 500 non-parametric bootstrap replicates.

\section{Results}

The starting point of our species delimitation procedure in Pandanusicola frogs is an assessment of their variation in mitochondrial DNA. Our tree based on 16S sequences (Fig. 1) agrees with previous 
analyses of relationships among Pandanusicola in that it does not satisfyingly resolve most of the nodes within the subgenus, but it is here included mainly to illustrate the amount of genetic divergence among species, as represented by the branch lengths in the tree. The tree recovered the previously assessed relationships (G. Alavobrunneus Blommers-Schlösser, 1979 sister to G. pulcher (Boulenger, 1882) and G. punctatus (Blommers-Schlösser, 1979) in a clade with the recently described G. milingilingy Bletz, Scherz, Rakotoarison, Lehtinen, Glaw \& Vences, 2018). Our analysis includes single representatives of all described species of Pandanusicola, as well as multiple samples for the two target lineages from northern Madagascar. We found all individuals of the target lineages forming genetically homogeneous monophyletic groups, representing (1) individuals from the Marojejy Massif, and (2) individuals from the Manongarivo and Montagne d'Ambre Massifs (see map in Fig. 2). Samples from Montagne d'Ambre and Manongarivo differed by only shallow divergences of $0.2 \%$ (uncorrected pairwise distances in the

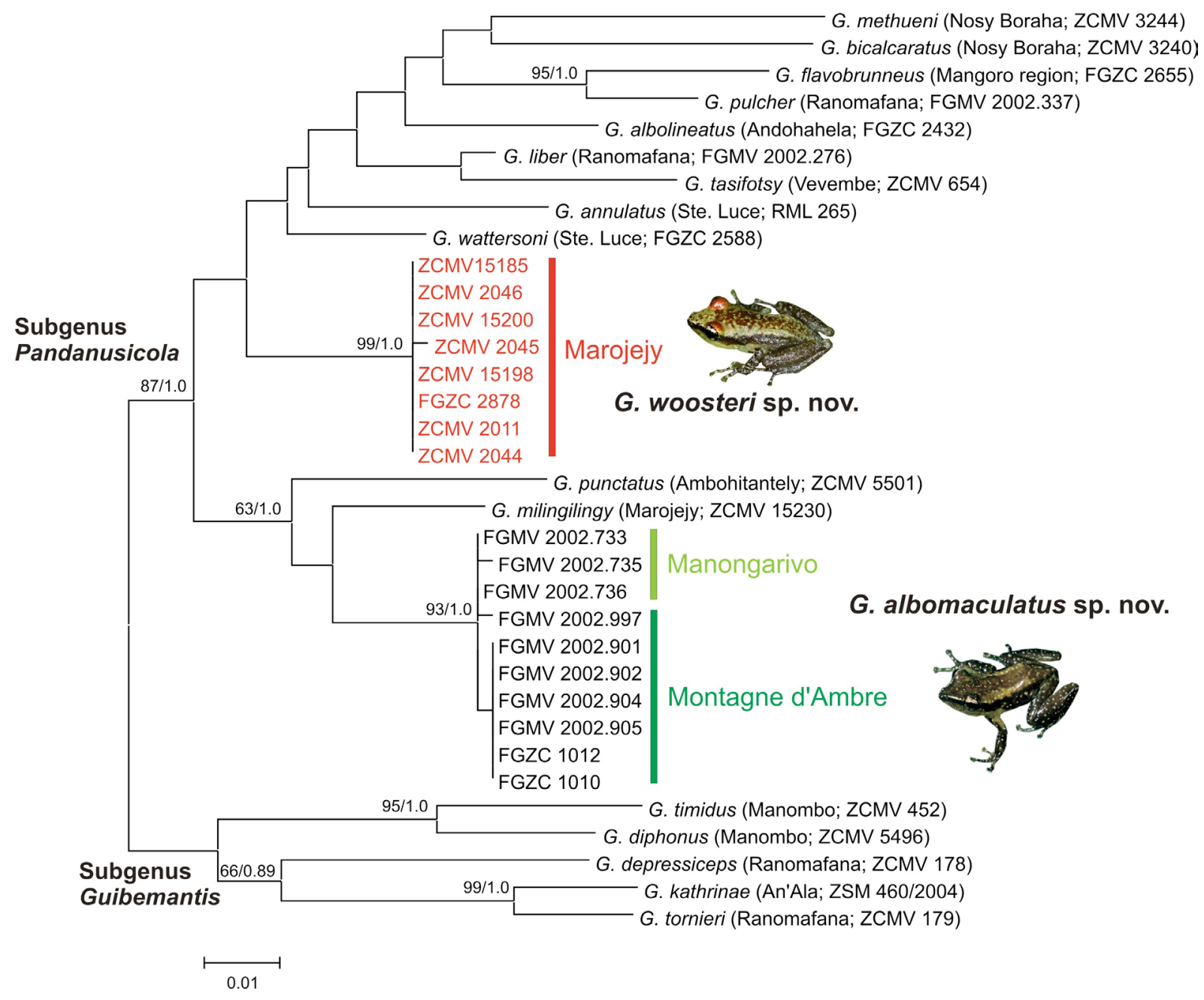

Fig. 1. Maximum Likelihood tree of species in the genus Guibemantis Dubois, 1992, subgenus Pandanusicola Glaw \& Vences, 1994 (rooted with the nominal subgenus). The tree is based on an analysis of $535 \mathrm{bp}$ of the mitochondrial $16 \mathrm{~S}$ rRNA gene and contains representatives of all valid species of Guibemantis. Numbers at nodes are bootstrap proportions from a Maximum Likelihood bootstrap analysis (500 replicates) in percent (BP), and posterior probabilities (PP) from Bayesian Inference (only shown for nodes with either BP $>60 \%$ or PP $>0.95$ ). Inset photos show the two new species described herein. 
16S gene). The Ambre/Manongarivo lineage was placed sister to G. milingilingy; it differed from this species by $4.0-4.3 \%$, and by $>5 \%$ from all other species including G. punctatus which bears some morphological similarities (see below). The Marojejy lineage had the lowest distance to G. wattersoni Lehtinen, Glaw \& Vences, 2011 (4.1\%) and to the morphologically highly distinct G. liber (4.8\%), and $>5 \%$ to all other species.

Phylogenetically, the Marojejy lineage had an unresolved position in the tree, splitting from a rather basal node within Pandanusicola. The Montagne d'Ambre/Manongarivo lineage was placed in a clade with G. milingilingy and G. punctatus. In both cases, the long branches of these lineages are indicative of a substantial genetic divergence to all other valid species of the subgenus.

The combined evidence from the high genetic divergences of these lineages in the 16S gene, clearly above the 3\% threshold proposed to define candidate species in Malagasy frogs (Vieites et al. 2009), their unresolved phylogenetic position suggesting they are not close relatives of any described species,

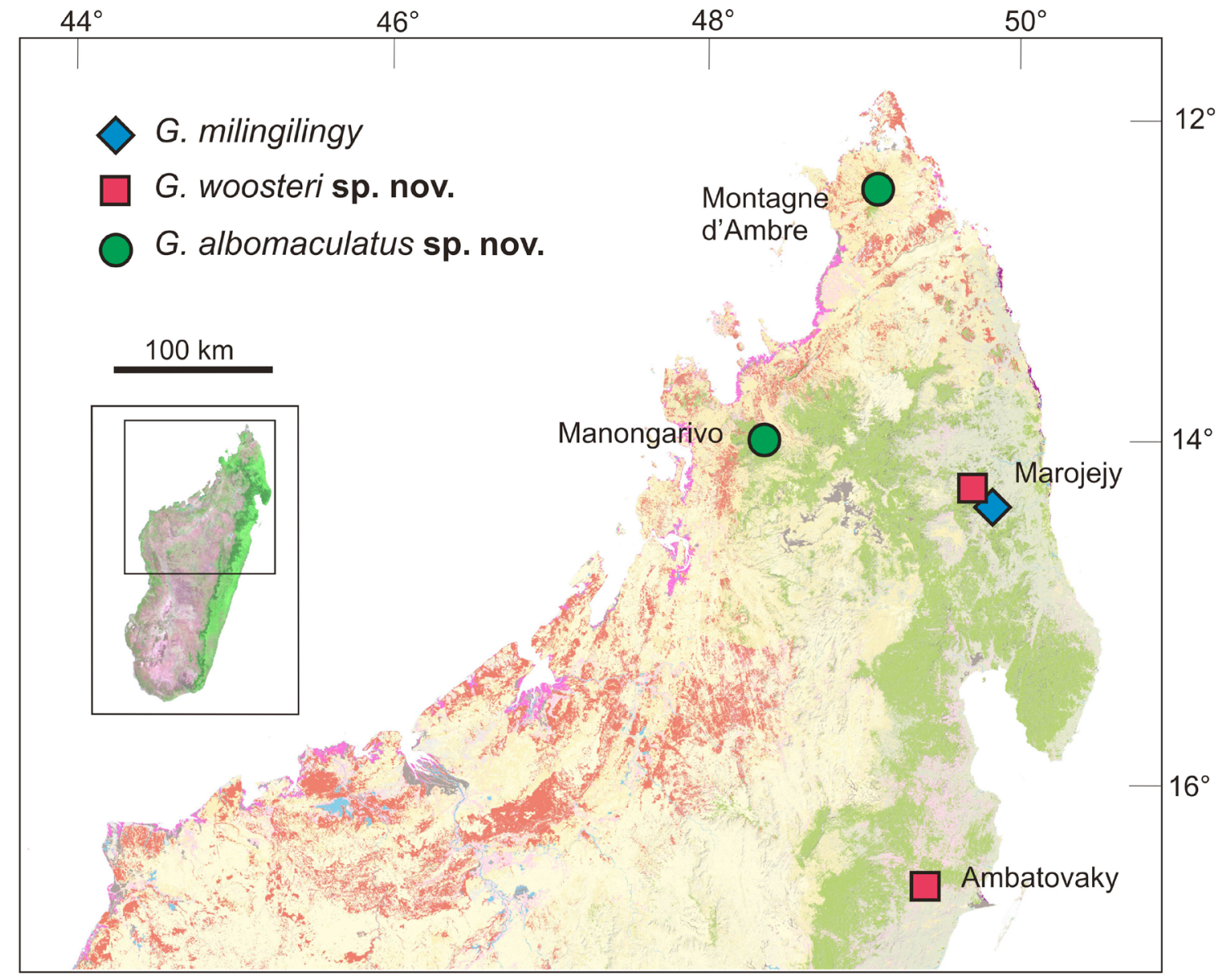

Fig. 2. Map of northern Madagascar, showing mostly verified distribution records of the two species of Guibemantis Dubois, 1992 described herein, and of the recently described G. milingilingy Bletz, Scherz, Rakotoarison, Lehtinen, Glaw \& Vences, 2018. The locality Ambatovaky is only based on similarities in coloration and is in need of confirmation. The map shows the remaining primary vegetation of Madagascar (www.vegmad.org), green colors indicating rainforest, brown/orange colors deciduous dry forest. 
and their differentiation in color pattern from other Pandanusicola (see below), suggest a status of independent evolutionary lineages warranting description as new species. In the following we formalize this conclusion and describe these lineages as Guibemantis albomaculatus sp. nov. and G. woosteri sp. nov.

\section{Description of new species}

Order Anura Fischer von Waldheim, 1813

Family Mantellidae Laurent, 1946

Genus Guibemantis Dubois, 1992

Subgenus Pandanusicola Glaw \& Vences, 1994

Guibemantis albomaculatus sp. nov. urn:1sid:zoobank.org:act:D33E461D-331B-4FE4-8808-DB476F9FB2AA

Figs 1-4

Suggested common name: White-spotted Malagasy Pandanus Frog.

\section{Diagnosis}

Assigned to the subgenus Pandanusicola of the genus Guibemantis based on its small body size, phytotelm-breeding habitats (in Pandanus plants), moderate webbing between toes, connected lateral metatarsalia, the presence of both inner and outer metatarsal tubercles, type 2 femoral glands in males, and DNA sequence similarities (Glaw \& Vences 2006). The new species is characterized by the unique combination of the following characters: (1) male SVL 18.9-22.9 mm, female SVL 20.9-26.7 mm, (2) two conspicuous parallel light-colored dorsolateral lines on the dorsum, (3) small white spots on the darkly colored arms, legs and flanks, (4) dark ventral surfaces to hands and feet, (5) distinct rostral stripe and (6) orange femoral glands.

\section{Etymology}

The specific epithet is used as a descriptive adjective and refers to the small white spots present on the arms, legs and flanks.

\section{Material examined}

\section{Holotype}

MADAGASCAR: adult $\hat{\partial}$, Montagne d'Ambre National Park, northern Madagascar [geographical coordinates not taken, but most likely from a Pandanus plant very close to the Gîte d'étape $\left(12.5270^{\circ} \mathrm{S}\right.$, $49.1720^{\circ} \mathrm{E}, 1055 \mathrm{~m}$ a.s.1.) or less likely from the Voie des mille arbres (ca $12.5200^{\circ} \mathrm{S}, 49.1756^{\circ} \mathrm{E}$, 1052 m a.s.1.)], 18 Feb. 2003, F. Glaw, R.D. Randrianiaina and A. Razafimanantsoa leg. [ZSM 0895/2003 (FGMV 2002.905)] (Fig. 3).

\section{Paratypes $(\mathrm{n}=19)$}

MADAGASCAR: 5 specs, Manongarivo Special Reserve, 20 Feb. 1992, C.J. Raxworthy, A. Raselimanana and J.B. Ramanamanjato leg. (UMMZ 212592-212596); 1 spec., Montagne d'Ambre National Park, Antomboka River, 1150 m a.s.l., 15 Nov. 1991, C.J. Raxworthy, A. Raselimanana and J.B. Ramanamanjato leg. (UMMZ 212585); 3 specs Montagne d'Ambre National Park, Antomboka River, 950 m a.s.l., 21 Nov. 1991, C.J. Raxworthy, A. Raselimanana and J.B. Ramanamanjato leg. (UMMZ 212587, UMMZ 212588, UMMZ 212591); 2 specs Manongarivo Special Reserve, "Camp 0", $13.9756^{\circ}$ S, $48.4267^{\circ}$ E, $688 \mathrm{~m}$ a.s.1., 1-2 Feb. 2003, F. Glaw, R.D. Randrianiaina and M. Vences leg. [ZSM 0816/2003 (FGMV 2002.735), ZMA 19582 (FGMV 2002.733)]; 1 spec., same collecting data as for preceding (UADBA uncatalogued, FGMV 2002.736); 1 spec., Montagne d'Ambre National 
Park, $12.5275^{\circ}$ S, $49.1725^{\circ}$ E, 1010 m a.s.1., 19 Mar. 2000, F. Glaw, K. Schmidt and M. Vences leg. [ZSM 496/2000 (FGMV 2000.356)]; 4 specs, Montagne d'Ambre National Park, same collection data as for holotype [ZSM 0893/2003 (FGMV 2002.0901), ZSM 0894/2003 (FGMV 2002.0904), UADBA uncatalogued (FGMV 2002.902), and ZMA 19660 (FGMV 2002.997)]; 1 ㅇ [UADBA uncatalogued (FGZC 1010)] and 1 juv. [UADBA uncatalogued (FGZC 1012)], Montagne d'Ambre National Park, Voie des mille arbres, $12.5167^{\circ} \mathrm{S}, 49.1767^{\circ}$ E, $1050 \mathrm{~m}$ a.s.l., 23 Feb. 2007, F. Glaw, P. Bora, H. Enting, J. Köhler and A. Knoll legs.

The six paratypes from UADBA and ZMA were not available for morphometric comparison, but were sequenced and attributed genetically to G. albomaculatus sp. nov. (see Fig. 1).

\section{Description of the holotype}

Adult male. Head longer than wide and slightly wider than body; snout rounded in dorsal, ventral and lateral views; canthus rostralis rounded; nostrils much nearer to tip of snout than to eye, internarial distance $83 \%$ of interorbital distance; tympanum distinct $42 \%$ of horizontal eye diameter; dark supratympanic fold present from posterior edge of eye around the tympanum nearly to the arm insertion; one small round patch of vomerine teeth medial between eye and choanae on either side of head; tongue damaged, shape of tip unknown. Arms thin, lower arm is $91 \%$ of hand length; relative finger length $1<2<4<3$, finger discs moderately enlarged and squared off at tips in a rounded ' $\mathrm{T}$ ' shape, only traces of webbing between fingers, subarticular tubercles prominent. Hindlimbs relatively thin, femur length $85 \%$ of tibia length, foot length $83 \%$ of tibia length; lateral metatarsalia connected; inner metatarsal tubercle oblong in shape $(0.6 \mathrm{~mm}$ in length, $0.3 \mathrm{~mm}$ in width); outer metatarsal tubercle round ( 0.4 in diameter); webbing formula between toes 1 (1) $2 \mathrm{i}(1) 2 \mathrm{e}(1) 3 \mathrm{i}(2) 3 \mathrm{e}(1.5) 4 \mathrm{i}(3) 4 \mathrm{e}(3) 5(1.5)$; relative length of toes $1<2<5<3<4$; toe discs moderately enlarged, width of fourth toe disc $58 \%$ of width of third finger disc. Femoral glands distinct, oblong in shape ( $4.4 \mathrm{~mm}$ long, $1.7 \mathrm{~mm}$ wide) with approximately 35 granules contained inside. Cloaca not clearly recognizable; skin is finely granular dorsally, more roughly granular ventrally. There is also a patch of whitish granules on the belly. For morphometric measurements see Table 1.

After seven years in preservative, the dorsal background coloration is medium brown which contrasts with the darker brown flanks. Two prominent light dorsolateral lines separate the medium brown color of the dorsum from the dark brown of the flanks. A single, relatively thick rostral stripe is present. Dorsal color of arms, legs, hands and feet is medium brown with abundant small white spots throughout. Vague light annuli are found on some digits just proximal to the finger and toe discs but are not prominent. Toe and finger discs have a similar dark coloration as the dorsal surface of the hands and feet, except for the discs of fingers I and II, which have a much lighter coloration. Venter is cream with abundant brown spots along jawline, chin and especially on the ventral surface of the hindlimbs. The pupil appears black and the iris is white.

\section{Coloration in life}

The life coloration of the holotype is unknown. However, based on photographs of live individuals from Manongarivo and Montagne d'Ambre (Fig. 4), there appear to be a number of coloration differences compared to preserved material. In life, the iris color is gold or bronze (white or gray in preservative). Portions of the arms and fingers as well as lateral areas of the head have a yellow or yellow-green color in life (beige in preservative). The more lightly colored toe and finger discs are a dull yellow (beige or whitish in preservative). The ventral skin is largely translucent such that chest and belly musculature and bones in the limbs are easily visible (not apparent in preservative). In males, femoral glands (type 2, as defined by Glaw et al. 2000) appear orange in life. Sexually mature males also possess a distinct white coloration on the lateral portions of the throat. A color photograph of a specimen of this species from Manongarivo is shown in Glaw \& Vences (2007: 203, fig. 4). 

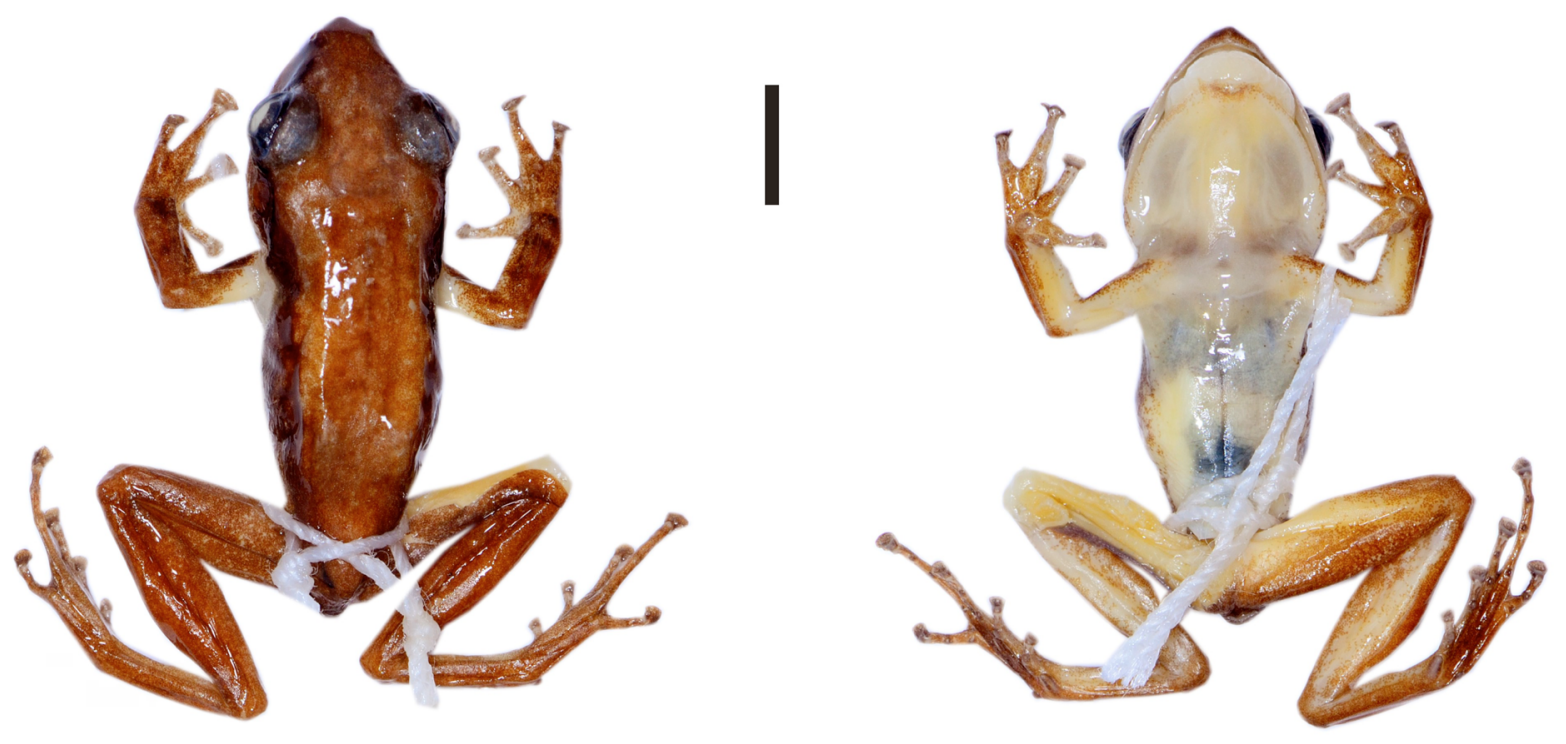

Guibemantis woosteri sp. nov. ZSM 5063/2005

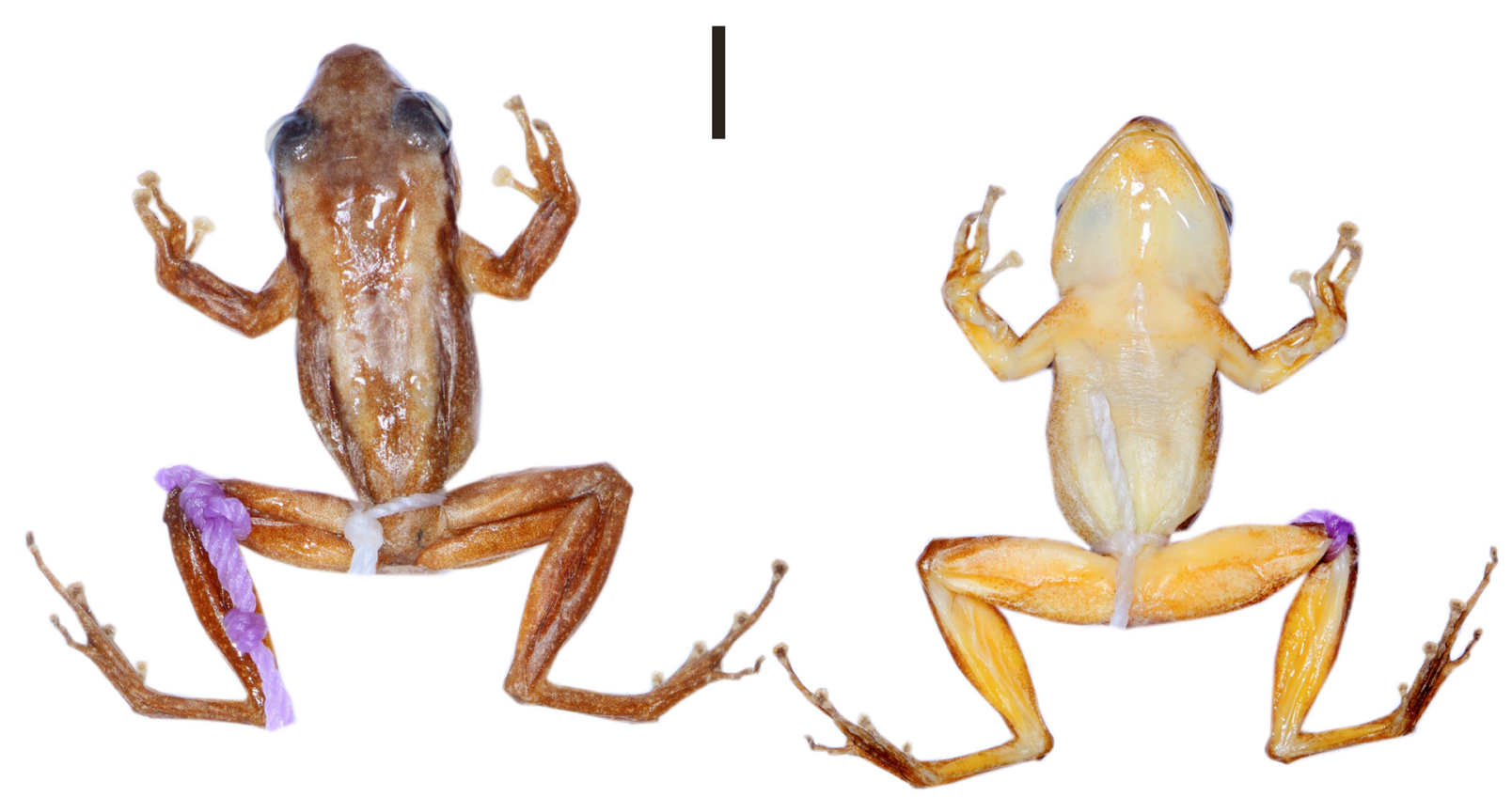

\section{Guibemantis albomaculatus sp. nov. ZSM 895/2003}

Fig. 3. Preserved holotype specimens of the two new species described herein, Guibemantis woosteri sp. nov. [ZSM 5063/2005 (ZCMV 2044)] and G. albomaculatus sp. nov. [ZSM 0895/2003 (FGMV 2002.905)], in dorsal and ventral view. Scale bars $=5 \mathrm{~mm}$. 


\section{Variation}

The new species is similarly sized to most other Pandanusicola (overall mean SVL $22.8 \pm 2.1 \mathrm{~mm}$, $\mathrm{n}=15$ ). Females appear to be larger on average than males (female mean SVL $24.0 \pm 1.7 \mathrm{~mm}, \mathrm{n}=9$; male mean SVL $21.3 \pm 1.5 \mathrm{~mm}, \mathrm{n}=6$ ). While all individuals seem to possess a dark rostral stripe, some individuals have an additional gold colored one medial to the first. The small white spots on the dorsal surface of the arms, legs and flanks also vary in coverage and density among individuals. Some individuals only possess them in abundance on the hindlimbs and sparingly elsewhere. Other individuals have an abundance of these spots not only on both limbs and the flanks, but also on the back and head as well. While yellowish dorsal coloration is present in all known individuals, the dorsal base color intermixed with it differs among individuals. Most individuals have a dorsal base color of medium to dark brown but one individual was notably lighter than other specimens examined (Fig. 4B). The prominence and length of the two parallel dorsal lines also varies among individuals, with those from Manongarivo typically being more distinct. Some individuals possess a small but distinct light-colored spot between the eyes, other individuals lack this feature. Many individuals possess no obvious markings on the dorsum but a few have several vague dark splotches. On the ventral surface, most individuals possess fine brown spots on the jawline and on the undersurface on the limbs. Other individuals have these spots on the throat and chest as well. No variation was observed in the webbing on the hand. However, webbing on the foot was variable for some digits (range, where variable, given in parentheses): 1(1) $2 \mathrm{i}$ (1) $2 \mathrm{e}$ (1) $3 \mathrm{i}(2)$ $3 \mathrm{e}(1-2) 4 \mathrm{i}(3) \mathrm{ee}(2.75-3) 5(1-2)$. The distinct light-colored annuli present before the terminal phalange of each digit, that are prominent in some Pandanusicola, are usually only weakly developed but can be conspicuous in some individuals.

\section{Differential diagnosis}

Among Pandanusicola, the new species is distinguished from G. annulatus Lehtinen, Glaw \& Vences, 2011, G. bicalcaratus (Boettger, 1913), G. flavobrunneus, G. liber, G. pulcher, G. punctatus and G. tasifotsy by the presence of two conspicuous parallel light-colored dorsolateral lines, by the presence of small white spots on more darkly colored arms, legs and flanks and by large genetic differences. By comparison, G. pulcher is a characteristic bright green in color with large irregular dark dorsal spots; G. bicalcaratus is yellowish or brownish dorsally with usually relatively few irregularly shaped dark spots; G. Alavobrunneus is much larger (up to $38 \mathrm{~mm} \mathrm{SVL}$; Glaw \& Vences 2007) and is primarily yellow with extensive brown dorsal markings; G. liber is rather variable in coloration but tends to be brownish overall, the entire surface of the throat of males is bright white, and this species does not breed in Pandanus plants; G. tasifotsy does not breed in Pandanus either and has a copper metallic coloration on the nares and/or eye orbits and prominent white lateral blotches; G. annulatus and G. punctatus are cream or olive-colored (respectively) and have abundant small dark spots; G. methueni (Angel, 1929) and G. wattersoni can have parallel dorsolateral light colored lines on the dorsum but most individuals lack this feature and it is usually poorly developed in those individuals that possess it. Furthermore, G. wattersoni is primarily a yellow or light brownish frog dorsally and the flanks and legs in $G$. wattersoni are always lightly colored whereas they are typically very dark in the new species. In G. methueni, the ventral surfaces of the hands and feet are very lightly colored, whereas they are dark in the new species. Guibemantis albolineatus (Blommers-Schlösser \& Blanc, 1991) lacks both vomerine teeth and a rostral stripe (both present in the new species), has a distinctly shaped snout that is square in dorsal and ventral view and is notably smaller in overall body size (see Table 1). The recently described G. milingilingy differs by lacking white spots (present in the new species), by having banded forelimbs (unbanded in the new species), by having yellow femoral glands in males (orange in the new species) and by having a mid-dorsal stripe (absent or poorly developed in the new species). No other described species of Pandanusicola has the combination of light colored parallel dorsal lines with small white spots on the dark unbanded arms, legs and flanks. 
Table 1 (continued on next page). Morphometric data (in $\mathrm{mm}$ ) of available specimens of the two new species, Guibemantis albomaculatus sp. nov. ( $\mathrm{n}=15)$, and G. woosteri sp. nov. $(\mathrm{n}=14)$, as well as comparative specimens of G. albolineatus (Blommers-Schlösser \& Blanc, 1991) $(\mathrm{n}=7)$. $\mathrm{HT}=$ holotype, $\mathrm{PT}=$ paratype, $\mathrm{LT}=$ lectotype, $\mathrm{PLT}=$ paralectotype, $\mathrm{SD}=$ standard deviation; see Material and methods for other abbreviations.

\begin{tabular}{|c|c|c|c|c|c|c|c|c|c|c|c|c|c|c|c|c|c|c|c|c|c|c|}
\hline Catalogue Number & Locality & Status & Sex & SVL & $F$ & $\mathrm{TL}$ & FOL & HL & $\mathrm{HW}$ & HAL & HAL/SVL & LLA & TD & ED & FGW & FGL & W3FD & W4TD & IOD & NSD & END & IND \\
\hline \multicolumn{23}{|l|}{ G. albomaculatus sp. nov. } \\
\hline UMMZ 212592 & Manongarivo & PT & 우 & 24.1 & 11.0 & 12.1 & 10.0 & 8.1 & 8.2 & 6.1 & 0.3 & 4.7 & 1.4 & 2.9 & - & - & 0.8 & 0.6 & 2.9 & 0.6 & 3.0 & 2.4 \\
\hline UMMZ 212593 & Manongarivo & PT & q & 24.5 & 10.4 & 11.3 & 9.3 & 8.3 & 8.4 & 6.9 & 0.3 & 5.1 & 1.6 & 2.9 & - & - & 0.9 & 0.9 & 3.5 & 0.8 & 2.8 & 1.9 \\
\hline UMMZ 212594 & Manongarivo & PT & o & 25.3 & 10.6 & 12.4 & 10.3 & 8.7 & 8.8 & 6.5 & 0.3 & 4.4 & 1.5 & 3.1 & - & - & 1.1 & 0.8 & 3.2 & 0.7 & 2.7 & 2.0 \\
\hline UMMZ 212595 & Manongarivo & PT & $\hat{0}$ & 21.6 & 9.4 & 10.9 & 9.1 & 7.7 & 6.6 & 6.1 & 0.3 & 4.5 & 1.5 & 2.8 & 1.0 & 5.1 & 0.7 & 0.6 & 2.6 & 0.6 & 2.2 & 2.2 \\
\hline UMMZ 212596 & Manongarivo & PT & $\hat{0}$ & 18.9 & 8.7 & 9.9 & 8.3 & 7.3 & 6.3 & 5.7 & 0.3 & 3.9 & 1.2 & 2.5 & 1.4 & 4.1 & 1.0 & 0.8 & 2.9 & 0.9 & 2.4 & 1.9 \\
\hline ZSM 0816/2003 / FGMV 2002.735 & Manongarivo & PT & $\delta$ & 22.4 & 10.2 & 11.1 & 9.3 & 7.8 & 7.5 & 5.7 & 0.3 & 5.2 & 1.3 & 2.9 & - & - & 1.2 & 1.0 & 3.3 & 0.9 & 2.7 & 2.3 \\
\hline UMMZ 212585 & Montagne d'Ambre & PT & $\hat{\sigma}$ & 22.9 & 10.1 & 10.5 & 9.3 & 7.7 & 7.9 & 6.0 & 0.3 & 5.7 & 1.5 & 2.8 & 1.3 & 4.9 & 0.9 & 0.8 & 3.4 & 0.7 & 2.7 & 2.2 \\
\hline UMMZ 212587 & Montagne d'Ambre & PT & o & 24.3 & 11.1 & 12.0 & 10.5 & 9.2 & 8.4 & 6.4 & 0.3 & 4.7 & 1.3 & 3.1 & - & - & 0.9 & 0.6 & 3.2 & 0.7 & 2.9 & 1.5 \\
\hline UMMZ 212588 & Montagne d'Ambre & PT & $\hat{\delta}$ & 20.0 & 9.2 & 9.5 & 8.0 & 6.7 & 6.9 & 4.7 & 0.2 & 3.6 & 1.2 & 2.5 & 1.5 & 3.7 & 0.9 & 0.6 & 2.9 & 0.9 & 2.4 & 1.8 \\
\hline UMMZ 212591 & Montagne d'Ambre & PT & o & 26.7 & 11.3 & 12.8 & 11.0 & 9.7 & 9.3 & 6.6 & 0.2 & 5.1 & 1.2 & 2.9 & - & - & 0.7 & 0.5 & 3.1 & 0.5 & 2.9 & 2.2 \\
\hline ZSM 496/2000 / FGMV 2000.356 & Montagne d'Ambre & PT & 우 & 22.2 & 9.5 & 10.4 & 9.4 & 6.7 & 7.9 & 5.5 & 0.2 & 4.7 & 1.2 & 2.8 & - & - & 1.1 & 0.6 & 3.0 & 0.9 & 2.5 & 2.3 \\
\hline ZSM 0874/2003 / FGMV 2002.869 & Montagne d'Ambre & PT & q & 24.4 & 10.8 & 11.7 & 10.7 & 8.0 & 8.9 & 6.5 & 0.3 & 5.6 & 1.2 & 3.6 & - & - & 1.4 & 0.9 & 3.7 & 1.0 & 2.7 & 2.5 \\
\hline ZSM 0893/2003 / FGMV 2002.901 & Montagne d'Ambre & PT & q & 23.3 & 9.4 & 10.6 & 10.1 & 7.8 & 7.7 & 6.5 & 0.3 & 4.9 & 1.1 & 2.8 & - & - & 1.2 & 0.8 & 3.6 & 0.8 & 2.4 & 2.4 \\
\hline ZSM 0894/2003 / FGMV 2002.904 & Montagne d'Ambre & PT & 우 & 20.9 & 9.2 & 10.2 & 8.8 & 7.9 & 7.1 & 4.6 & 0.2 & 4.4 & 1.0 & 2.8 & - & - & 0.8 & 0.6 & 2.5 & 0.9 & 2.3 & 2.4 \\
\hline ZSM 0895/2003 / FGMV 2002.905 & Montagne d'Ambre & HT & $\hat{0}$ & 22.0 & 9.0 & 10.6 & 8.8 & 7.1 & 7.6 & 5.6 & 0.3 & 5.1 & 1.1 & 2.6 & 1.4 & 4.4 & 1.2 & 0.7 & 2.9 & 0.8 & 2.3 & 2.4 \\
\hline
\end{tabular}

\begin{tabular}{|c|c|c|c|c|c|c|c|c|c|c|c|c|c|c|c|c|c|c|c|c|c|c|}
\hline UMMZ 212601 & Marojejy & PT & o & 21.8 & 10.2 & 11.4 & 9.9 & 7.9 & 7.0 & 6.1 & 0.3 & 5.1 & 1.3 & 3.2 & 1.4 & 4.8 & 0.9 & 0.7 & 2.9 & 1.0 & 2.5 & 2.0 \\
\hline UMMZ 212602 & Marojejy & PT & 0 & 21.5 & 9.9 & 11.2 & 9.9 & 7.5 & 6.9 & 6.1 & 0.3 & 4.4 & 1.3 & 2.8 & 1.3 & 4.4 & 0.9 & 0.8 & 2.9 & 0.7 & 2.6 & 2.4 \\
\hline UMMZ 212604 & Marojejy & PT & 0 & 21.8 & 9.8 & 11.0 & 10.1 & 8.5 & 7.3 & 5.7 & 0.3 & 4.6 & 1.4 & 3.2 & 1.5 & 4.7 & 0.9 & 0.6 & 2.6 & 0.8 & 2.2 & 1.9 \\
\hline UMMZ 212605 & Marojejy & PT & $\delta$ & 21.1 & 9.5 & 10.5 & 9.5 & 7.0 & 7.4 & 6.1 & 0.3 & 4.7 & 1.2 & 2.8 & 1.7 & 5.1 & 1.0 & 0.8 & 2.8 & 0.8 & 2.1 & 2.2 \\
\hline UMMZ 212606 & Marojejy & PT & $\sigma^{\pi}$ & 20.4 & 9.6 & 11.0 & 9.2 & 7.7 & 7.0 & 5.7 & 0.3 & 4.7 & 1.5 & 2.9 & 1.4 & 4.1 & 1.1 & 0.7 & 3.2 & 0.7 & 2.2 & 2.1 \\
\hline UMMZ 212613 & Marojejy & PT & 우 & 23.9 & 10.5 & 11.6 & 9.0 & 8.0 & 7.5 & 6.3 & 0.3 & 4.5 & 1.4 & 3.0 & - & - & 1.0 & 0.8 & 3.1 & 0.7 & 2.3 & 2.2 \\
\hline UMMZ 212615 & Marojejy & PT & o & 23.0 & 10.4 & 11.7 & 10.5 & 8.0 & 8.0 & 6.6 & 0.3 & 5.2 & 1.5 & 3.3 & - & - & 1.0 & 0.9 & 2.8 & 1.0 & 2.2 & 2.7 \\
\hline UMMZ 212617 & Marojejy & PT & o & 22.5 & 10.1 & 11.5 & 10.2 & 8.2 & 7.0 & 5.7 & 0.3 & 5.1 & 1.6 & 2.6 & - & - & 0.8 & 0.8 & 3.1 & 0.7 & 2.4 & 2.2 \\
\hline UMMZ 191339 & Ambatovaky Reserve & - & $\hat{\sigma}$ & 21.7 & 10.4 & 11.5 & 8.6 & 8.3 & 6.8 & 5.3 & 0.2 & 4.4 & 1.2 & 2.8 & 1.7 & 4.2 & 0.8 & 0.7 & 2.8 & 0.9 & 2.6 & 2.2 \\
\hline UMMZ 191340 & Ambatovaky Reserve & - & 우 & 24.5 & 10.8 & 12.1 & 10.1 & 9.0 & 7.1 & 6.2 & 0.3 & 4.3 & 1.3 & 2.9 & - & - & 0.9 & 0.6 & 3.1 & 1.2 & 2.9 & 2.3 \\
\hline UMMZ 191343 & Ambatovaky Reserve & - & $\hat{0}$ & 21.5 & 9.5 & 10.2 & 8.1 & 7.7 & 6.7 & 5.2 & 0.2 & 3.7 & 1.3 & 3.0 & 1.2 & 4.1 & 0.7 & 0.6 & 2.8 & 0.8 & 2.8 & 1.9 \\
\hline
\end{tabular}


Table 1 (continued).

\begin{tabular}{|c|c|c|c|c|c|c|c|c|c|c|c|c|c|c|c|c|c|c|c|c|c|c|}
\hline Catalogue Number & Locality & Status & Sex & SVL & FL & TL & FOL & $\mathrm{HL}$ & HW & HAL & HAL/SVL & LLA & TD & ED & FGW & FGL & W3FD & W4TD & IOD & NSD & END & IND \\
\hline UMMZ 191344 & Ambatovaky R & - & $0^{2}$ & 19.4 & 9.2 & 10.4 & 9.2 & 7.6 & 6.0 & 5.4 & 0.3 & 4.8 & 1.1 & 2.9 & 1.1 & 3.7 & 1.0 & 0.6 & 2.8 & 0.7 & 1.8 & 2.0 \\
\hline ZSM 5062/2005 / ZCMV 2011 & Marojejy & PT & $\delta$ & 20.8 & 10.3 & 10.6 & 9.0 & 6.9 & 7.3 & 6.0 & 0.3 & 5.1 & 1.1 & 3.1 & 1.6 & 5.0 & 1.1 & 0.8 & 2.2 & 0.7 & 2.3 & 2.3 \\
\hline ZSM 5063/2005 / ZCMV 2044 & Marojejy & HT & 우 & 24.9 & 10.5 & 11.5 & 10.1 & 8.8 & 8.3 & 5.8 & 0.2 & 5.4 & 1.3 & 3.4 & - & - & 1.2 & 1.1 & 3.3 & 1.1 & 2.7 & 2.6 \\
\hline
\end{tabular}

G. albolineatus (Blommers-Schlösser

ZSM 171/2005/FGZC 2432

ZSM 172/2005 / FGZC 2433

Andohahela

MNHN 1972.2074

Andohahela

MNHN 1972.2082

Andohahela

MNHN 1972.2077

Andohahela

MNHN 1972.2079

Andohahela

MNHN 1972.2080

Andohahela

Andohahela

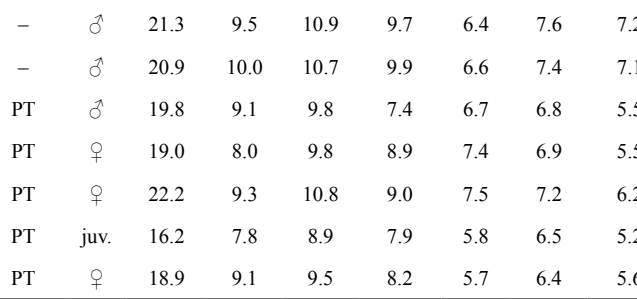

$\begin{array}{llllllllllll}0.34 & 5.1 & 1.2 & 2.8 & 1.8 & 5.0 & 1.3 & 1.2 & 3.2 & 1.2 & 2.2 & 2.4 \\ 0.34 & 5.1 & 1.0 & 2.8 & 2.1 & 5.7 & 1.0 & 0.9 & 2.9 & 1.3 & 2.1 & 2.6 \\ 0.28 & 4.3 & 1.1 & 2.5 & 1.4 & 4.7 & 1.0 & 0.9 & 2.4 & 0.8 & 2.1 & 2.3 \\ 0.29 & 4.7 & 1.1 & 2.6 & - & - & 0.9 & 0.8 & 2.8 & 0.6 & 2.1 & 2.3 \\ 0.28 & 4.9 & 1.0 & 2.9 & - & - & 1.2 & 0.8 & 3 & 0.6 & 2.2 & 2.7 \\ 0.32 & 4.5 & 1.0 & 2.9 & - & - & 0.9 & 0.5 & 2.5 & 0.7 & 1.9 & 2.3 \\ 0.30 & 4.4 & 1.0 & 2.5 & - & - & 1.0 & 0.7 & 2.5 & 0.8 & 2.0 & 2.4\end{array}$




\section{Distribution}

At present G. albomaculatus sp. nov. is known from rainforest habitats in two areas: the Manongarivo Special Reserve (type locality) and Montagne d'Ambre National Park, both in northern Madagascar (Fig. 2). The elevational range so far documented is from $950-1150 \mathrm{~m}$.

Based on the limited knowledge of the distribution, we suggest a conservation status of "Data Deficient".
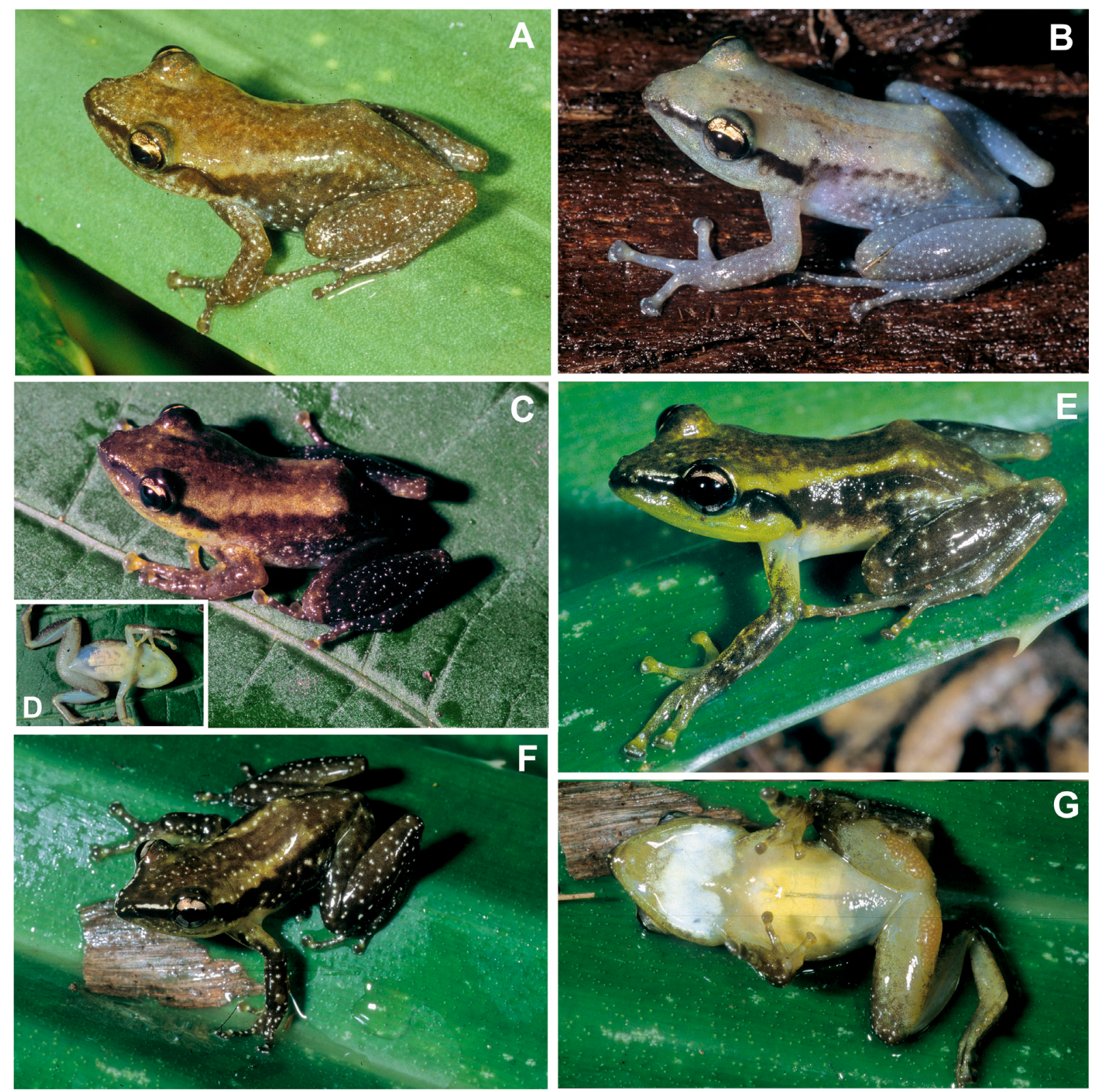

Fig. 4. Guibemantis albomaculatus sp. nov. in life. A-B. Two specimens with unknown sex or voucher numbers from Montagne d'Ambre. C-D. o, from Montagne d'Ambre, probably ZSM 894/2003 (FG/ MV 2002.904). e. Specimen from Manongarivo with unknown sex or voucher number. $\mathbf{F}-\mathbf{G}$. $\hat{\jmath}$, from Manongarivo, ZSM 816/2003 (FG/MV 2002.735). 


\section{Natural history}

Little is known of the natural history of this species. Specimens have only been collected from Pandanus plants and are probably obligate Pandanus breeders, like most other species in this group. Vocalizations have not been recorded and eggs and larvae have yet to be documented.

\section{Available names and comparisons}

The only available synonyms that could possibly be applied to this species are Gephyromantis albogularis Guibé, 1947 and Gephyromantis variabilis Millot \& Guibé, 1951, both of which were confidently assigned to Guibemantis liber by Lehtinen et al. (2011).

Males of Guibemantis liber have a throat that is bright white over its entire surface. The whitish coloration on the throat of males in G. albomaculatus sp. nov. does not cover the entire surface nor is it as brightly white as in G. liber.

\section{Remark}

This species has been previously listed as Guibemantis sp. aff. albolineatus "Manongarivo" in Glaw \& Vences (2007: 202-203), Guibemantis bicalcaratus (Manongarivo) in Lehtinen et al. (2007) and Guibemantis sp. Ca12 in Vieites et al. (2009) and Perl et al. (2014).

Guibemantis woosteri sp. nov.

urn:1sid:zoobank.org:act:BB4E147F-EB7A-41F9-9E1B-94B92521EE7F

Figs $1-3,5$

Suggested common name: Wooster's Malagasy Pandanus Frog.

\section{Diagnosis}

Assigned to the subgenus Pandanusicola of the genus Guibemantis based on its small body size, phytotelm-breeding habitats (in Pandanus plants), moderate webbing between toes, connected lateral metatarsalia, the presence of both inner and outer metatarsal tubercles, type 2 femoral glands in males, and DNA sequence similarities (Glaw \& Vences 2006). The new species is characterized by the unique combination of the following characters: (1) male SVL 19.4-21.8 mm, (2) two fairly conspicuous parallel light-colored dorsolateral lines on the dorsum, (3) well-defined dark bars on the forearms and sometimes on the legs, (4) a conspicuous light area near the forearm insertion, (5) dark ventral surfaces to hands and feet, (6) thick, single dark rostral stripe, (7) distinctly reddish color dorsally surrounding the eyes, (8) white spots of the dorsum and limbs and (9) gray femoral glands in males.

\section{Etymology}

This new species is dedicated to the College of Wooster and its faculty, staff, students and alumni in celebration of 150 years of educational excellence.

\section{Material examined}

Holotype

MADAGASCAR: adult + , Marojejy National Park at "Camp Simpona", $14.437^{\circ} \mathrm{S}, 49.743^{\circ} \mathrm{E}$, 1326 m a.s.l., 18 Feb. 2005, F. Glaw, M. Vences and R.D. Randrianiaina leg. [ZSM 5063/2005 (ZCMV 2044)] (Fig. 3).

Paratypes $(\mathrm{n}=15)$

MADAGASCAR: 8 adults, Manantenina River in Marojejy National Park, 700-1300 m a.s.1., Nov. 1992, R.A. Nussbaum, C.J. Raxworthy, A. Razafimanantsoa and A. Razafimanantsoa leg. (UMMZ 212601- 
212602, UMMZ 212604-212606, UMMZ 212613, UMMZ 212615, UMMZ 212617); adult $\delta ึ$, same data as for holotype [ZSM 5062/2005 (ZCMV 2011)]; 1 , , Marojejy National Park, Camp 3 "Simpona", $14.4366^{\circ}$ S, $49.7434^{\circ}$ E, 1325 m a.s.1., 17 Nov. 2017, M.D. Scherz, A. Rakotoarison, M. Bletz, M. Vences and J. Razafindraibe leg. [ZSM 425/2016 (ZCMV 15185)]; 1 ô and 1 juv., Marojejy, between Camp 2 "Marojejia" and Camp 3 "Simpona", no coordinates taken, 18 Nov. 2016, M.D. Scherz, A. Rakotoarison, M. Bletz, M. Vences and J. Razafindraibe leg. [ZSM 426/2016 (ZCMV 15198), UADBA uncatalogued (ZCMV 15200)]; 1 spec., Marojejy National Park, same data as for holotype, but collected on 16 Feb. 2005 [(FGZC 2878), UADBA uncatalogued]; 1 spec., same data as holotype (ZCMV 2045); 1 spec., same data as holotype, but collected above Camp Marojejia (ZCMV 2046).

The paratypes from UADBA were not available for morphometric comparison, but were sequenced and attributed genetically to G. woosteri sp. nov. (see Fig. 1).

\section{Referred specimens}

Based on similarity in coloration (no genetic data available), we also tentatively assign to this species the series UMMZ 191339-191340 and UMMZ 191343-191344; adults from Ambatovaky Special Reserve (600-800 m), collected by C.J. Raxworthy on 21 February 1990.

\section{Description of the holotype}

Adult female. Head longer than wide and slightly wider than body; snout rounded in dorsal, ventral and lateral views; canthus rostralis rounded; nostrils very near to the tip of snout, internarial distance $79 \%$ of interorbital distance; tympanum distinct $38 \%$ of horizontal eye diameter; very dark and prominent supratympanic fold present from posterior edge of eye around the tympanum nearly to the arm insertion; one small round patch of vomerine teeth medial between eye and choanae on either side of head; tongue stout and strongly bifid. Arms thin, lower arm is $93 \%$ of hand length; relative finger length $1<2<4<3$, finger discs moderately enlarged and squared off at tips in a rounded ' $\mathrm{T}$ ' shape, only traces of webbing between fingers, subarticular tubercles prominent. Hindlimbs relatively thin, femur length $91 \%$ of tibia length, foot length $88 \%$ of tibia length; lateral metatarsalia connected; inner metatarsal tubercle oblong, ( 0.8 in length, 0.3 in width); outer metatarsal tubercle round ( 0.3 in diameter); webbing formula between toes 1 (1) $2 \mathrm{i}(1) 2 \mathrm{e}(1) 3 \mathrm{i}(2) 3 \mathrm{e}(2) 4 \mathrm{i}(2.75) 4 \mathrm{e}(3) 5(1.5)$; relative length of toes $1<2<5<3<4$; toe discs moderately enlarged, width of fourth toe disc $92 \%$ of width of third finger disc. Cloaca not clearly recognizable; skin is finely granular dorsally, more coarsely granular ventrally. For morphometric measurements see Table 1. A sample of muscle was taken from right leg for genetic analysis.

After 13 years in preservative, the dorsal background coloration is a medium brown with the flanks much darker brown. Starting at the snout tip, there is a distinct color change along the dorsolateral area (medium brown medially, dark brown laterally). A few vague light spots are present, but there are no conspicuous dorsal markings. A thick, dark rostral stripe is present. The dorsal surface of arms, hands and fingers is medium brown with darker bands on the forearms. Dorsal surface of legs, feet and toes is a uniform medium brown with no obvious markings. The skin on the upper arms near the articulation with the body conspicuously lacks any coloration and this contrasts markedly with the more distal portions of the arm that are darker. Finger discs are fairly dark brown dorsally and ventrally with some lighter areas (especially fingers I and II). Toe discs are similar. Fairly obvious white annuli are present on many digits. Ventral surface cream with dark spots on jawline and ventral surface of thighs, hands and feet.

\section{Coloration in life}

The life coloration of the holotype is unknown. However, based on photographs of live individuals from Marojejy (Fig. 5), there are several clear coloration differences compared to preserved specimens. The small white spots, often prominent in life, are not usually obvious after preservation in alcohol. The iris, which is gold in life, is white or gray in preservative. The portions of the limbs, dorsum and head, 
medium brown in preservative, appear yellowish-green in life. Moreover, at least some individuals have a prominent red color on the eye orbits; there is no indication of this in preservative. The ventral skin is semi-translucent in life such that chest and belly musculature are visible (not apparent in preservative). In males, femoral glands (type 2, as defined by Glaw et al. 2000) appear gray in life with large granules in the gland, each of which has a white spot (Fig. 5C). Sexually mature males also possess a white coloration on portions of the throat.

\section{Variation}

Like most Pandanusicola, this new species is small (overall mean $22.1 \pm 1.6 \mathrm{~mm} \mathrm{SVL}, \mathrm{n}=14$ ). Females are larger (mean $23.8 \pm 1.0 \mathrm{~mm} \mathrm{SVL}, \mathrm{n}=5$ ) than males (mean $21.1 \pm 0.8 \mathrm{~mm} \mathrm{SVL}, \mathrm{n}=9$ ) on average. Some individuals have relatively few small white dorsal spots (primarily on the hindlimbs), while others have dense spots over much of the dorsal surfaces (contrast Fig. 5A and 5B). The light dorsolateral lines on the dorsum are conspicuous in some individuals but much less so in others. Dark spotting on the dorsum also varies from none to many. Dark bars on legs vary from reasonably distinct (Fig. 5A) to inconspicuous (Fig. 5B). Head coloration can be variable also, with several specimens having a distinctly lighter coloration anterior to the eyes than posterior and one specimen possessed a distinct interocular bar. Many, but not all, specimens had a distinct light spot in the middle of the snout. The
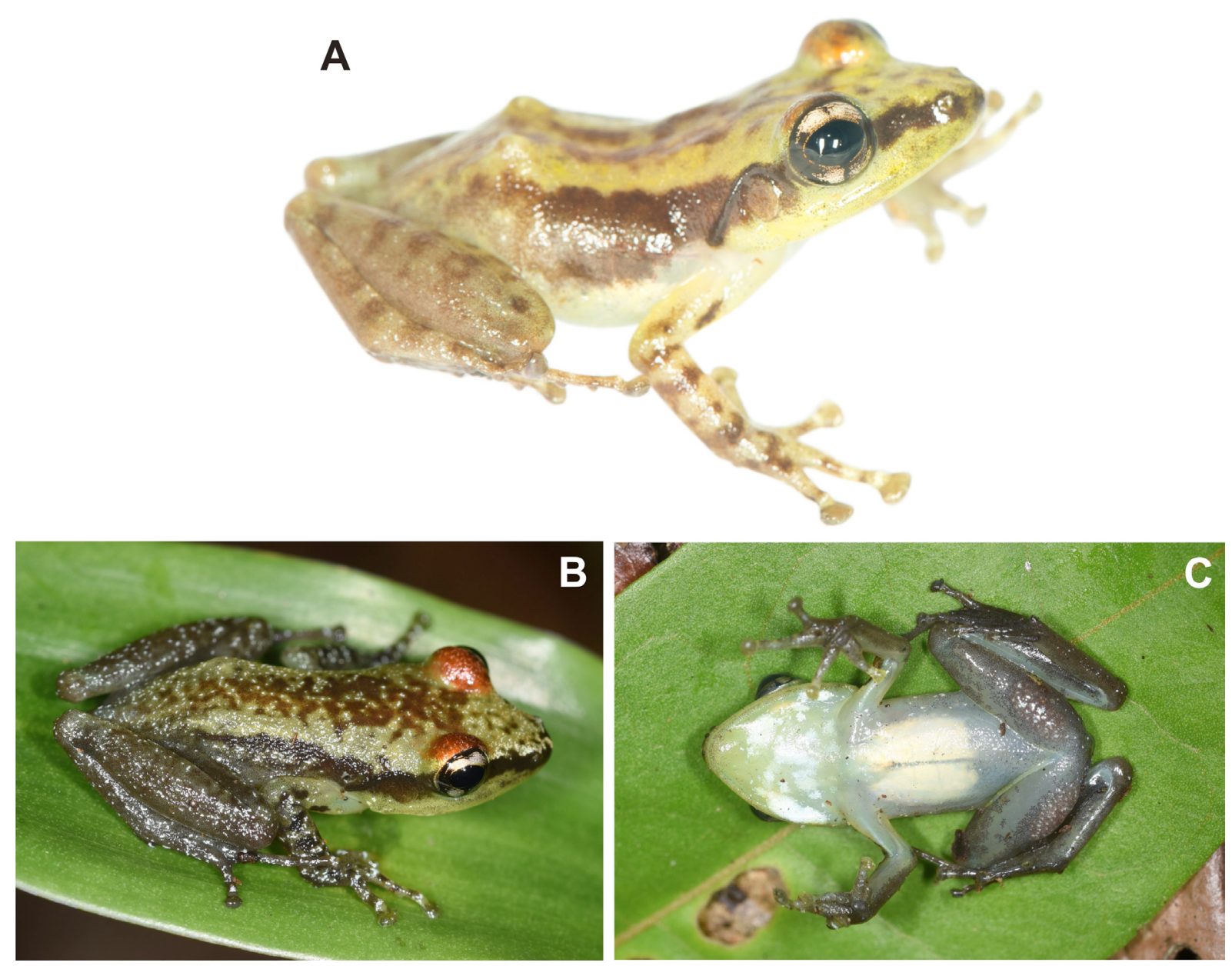

Fig. 5. Guibemantis woosteri sp. nov. in life. A. ZSM 425/2016 (ZCMV 15185) from Marojejy. B-C. ZSM 426/2016 (ZCMV 15198) from Marojejy in dorsolateral and ventral view. 
color of the digits and toepads also varies. Some individuals have distinct dark bars on the digits and this seems to be an extension of the bars on the forearms. The color of the toepads is similarly variable with the pads on some digits being dark and other digits being light. A few individuals had indications of faint annuli on the digits proximal to the toepads or a second rostral line parallel to the first (as in G. annulatus and $G$. wattersoni), however, these are usually not well developed. Ventrally, coloration varies from having dark markings only along the jawline to individuals with dark spotting on the throat, chest and/or thighs. The ventral surfaces of the hands and feet are apparently always dark. One individual (UMMZ 212604) had especially rough granular patches on the belly, reminiscent of those recently described from G. tasifotsy. No variation was observed in the webbing on the hand. However, webbing on the foot was variable for some digits (range, where variable, given in parentheses): 1(1) $2 \mathrm{i}(1) 2 \mathrm{e}(1) 3 \mathrm{i}(2) 3 \mathrm{e}(1-2)$ $4 \mathrm{i}(2.5-3) 4 \mathrm{e}(2.5-3) 5(1-2)$.

\section{Differential diagnosis}

Among Pandanusicola, the new species is distinguished from $G$. annulatus, G. bicalcaratus, G. flavobrunneus, G. liber, G. pulcher, G. punctatus and G. tasifotsy by the presence of two conspicuous parallel dorsolateral light-colored lines on the dorsum, by the presence of small white spots on more darkly colored arms, legs and flanks and by large genetic differences. By comparison, G. pulcher is a characteristic bright green in color with large irregular dark dorsal spots; G. bicalcaratus, is yellowish or brownish dorsally with usually relatively few irregularly shaped dark spots; G. Alavobrunneus is much larger (up to $38 \mathrm{~mm}$ SVL; Glaw \& Vences 2007) and is primarily yellow with extensive brown dorsal markings; $G$. liber is rather variable in coloration but tends to be brownish overall, the entire surface of the throat of males is bright white, and this species does not breed in Pandanus plants; G. tasifotsy does not breed in Pandanus either, and has a copper metallic coloration on the nares and/ or eye orbits and prominent white lateral blotches; G. annulatus and G. punctatus are cream or olivecolored, respectively, and have abundant small, well-defined dark spots; G. methueni and G. wattersoni can have parallel light-colored dorsolateral lines on the dorsum but most individuals lack this feature and, if present, it is usually poorly developed. Furthermore, G. wattersoni is a yellow or light brownish frog dorsally and its flanks and legs are always lightly colored whereas they are typically dark in the new species. In G. methueni, the ventral surfaces of the hands and feet are very lightly colored, whereas they are dark in the new species. Guibemantis albolineatus lacks both vomerine teeth and a rostral stripe (both present in the new species), has a distinctly shaped snout that is square in dorsal and ventral view and is notably smaller in overall body size (see Table 1). The recently described G. milingilingy differs by lacking the characteristic white spots on the dorsum and limbs (versus presence), by lacking the reddish colored skin on the eye orbits (versus presence) and by having yellow femoral glands in mature males (gray in the new species). Finally, G. woosteri sp. nov. differs from G. albomaculatus sp. nov. in having well-defined dark bars on the forearms and sometimes on the legs, a conspicuous light area near the forearm insertion (both of which G. albomaculatus sp. nov. lacks) and gray femoral glands in males with distinct white spots (femoral glands are orange in male G. albomaculatus sp. nov.). No other described species of Pandanusicola has the combination of light colored parallel dorsolateral lines with small white spots on the legs and flanks and well-defined dark bars on the forearms.

\section{Distribution}

Currently, G. woosteri sp. nov. is reliably known only from mid-elevation rainforests in Marojejy National Park, the type locality, in the North-East of Madagascar (Fig. 2), from roughly 700-1325 m a.s.l. In addition, we here consider specimens from the Ambatovaky Special Reserve in the Northern Central East of the island as possibly belonging to this species (Fig. 2), but this identification requires confirmation by molecular data.

Based on the limited knowledge of the distribution, we suggest a conservation status of "Data Deficient". 


\section{Natural history}

Only known from Pandanus plants. One adult female attributed to this species (UMMZ 212617) had four visible eggs in the body cavity (egg diameter $0.8 \mathrm{~mm}$ ) and another (UMMZ 191340; from Ambatovaky) had six (egg diameter $1.8 \mathrm{~mm}$ ) possibly suggesting a small clutch size. Tadpoles and breeding vocalizations are unknown.

\section{Available names and comparisons}

The only available synonyms that could possibly be applied to this species are Gephyromantis albogularis Guibé, 1947 and Gephyromantis variabilis Millot \& Guibé, 1951, both of which were confidently assigned to Guibemantis liber by Lehtinen et al. (2011). Guibemantis liber males have a throat that is bright white over its entire surface. The whitish coloration on the throat of males in G. woosteri sp. nov. does not cover the entire surface nor is it as brightly white as in G. liber.

\section{Remark}

In Vieites et al. (2009) and Perl et al. (2014), the holotype of G. woosteri sp. nov. (ZSM 5063/2005 / ZCMV 2044) and one paratype (ZSM 5062/2005 / ZCMV 2011) were listed as two different candidate species (Ca15 and Ca17, respectively). However, the $16 \mathrm{~S}$ sequence data reported here show them to be nearly identical genetically (Fig. 1) and they are also morphologically similar (Table 1). Thus, we consider them to be conspecific. In another earlier molecular analysis, Lehtinen et al. (2007) found the holotype of $G$. woosteri sp. nov. (ZSM 5063/2005) to be phylogenetically related to UMMZ 212597 (also from Marojejy) and UMMZ 212922 from Cap Est (in the same region, but further east on the coast). However, these forms are $7.3 \%$ and $8.1 \%$ different in the $12 \mathrm{~S}$ and $16 \mathrm{~S}$ mitochondrial genes (Lehtinen et al. 2007) and are morphologically distinct from G. woosteri sp. nov. We have, therefore, not included these specimens in the definition of $G$. woosteri sp. nov. as they likely represent additional undescribed taxa.

\section{Discussion}

The description of two new Pandanusicola herein brings the number of described species in Guibemantis to 18 (five in the subgenus Guibemantis and 13 in the subgenus Pandanusicola). However, numerous additional candidate species that are either highly divergent genetically or morphologically distinctive (or both) remain to be assessed, especially in Pandanusicola (Lehtinen et al. 2007; Vieites et al. 2009). Since these small frogs can be confusingly variable morphologically and tend not to vocalize very conspicuously, other characters may need to be evaluated to help assess the true diversity in this group.

One character that may be useful in this regard is the structure and the color of femoral glands in males. While the precise function of these structures remains unclear, they are sexually dimorphic and thus may be under selection as important mating barriers between species (Glaw et al. 2000). If this is true, they are likely to be useful in distinguishing closely related forms. In Pandanusicola, two species (G. liber and G. tasifotsy) have femoral glands that cover much of the thigh and do not have clear boundaries (Lehtinen et al. 2012). As far as is known in all other Pandanusicola, the femoral glands are smaller (often covering only a relatively small portion of the thigh). However, the size and distribution of granules within the femoral glands seem to vary substantially in different species. For example, in G. albomaculatus sp. nov., G. methueni, G. milingilingy and G. woosteri sp. nov., the granules are large ( 30-36 granules per gland based on Figs 4G and 5C and photos in Lehtinen et al. 2011; Vences et al. 2013 ). By contrast, G. punctatus has $\sim 65$ granules per gland and G. annulatus has $\sim 120$ (based on photos in Lehtinen et al. 2011). 
There also appear to be distinct differences among Pandanusicola species in femoral gland color, as well as in the contrast of the femoral gland color with that of the adjacent skin on the thigh. For example, in G. milingilingy the femoral glands are yellow (Bletz et al. 2018) and in G. albomaculatus sp. nov. they are orange (Fig. 4G), but in both cases they contrast markedly in color from the surrounding tissue. In G. woosteri sp. nov. the femoral glands are dark gray and in G. methueni and $G$. wattersoni they are beige, but in these cases they do not differ strongly in color compared to the adjacent area of the thigh. While it is likely that the appearance of the femoral glands differs depending on the time of year and the physiological state of the individual (Blommers-Schlösser 1979), these characters may nonetheless be useful to distinguish otherwise similar species. Femoral gland color and contrast as well as other coloration patterns not apparent in preserved specimens seem to be important in distinguishing many species of Pandanusicola. To help in this regard, we encourage others to take dorsal and ventral photographs of live individuals as standard practice when collecting specimens.

Our study increases the number of amphibian species endemic to northern Madagascar, a region where in-situ diversification processes have resulted in a high diversity of micro-endemic species in many groups (Brown et al. 2016). The example of Guibemantis albomaculatus sp. nov. also adds to the list of species that are known both from Montagne d'Ambre and from Manongarivo and/or Tsaratanana (Andreone et al. 2009). In some cases, the populations from these lineages have deep divergences [e.g., in Gephyromantis ambohitra (Vences \& Glaw, 2001); Vences et al. 2017], whereas the divergences are very shallow in G. albomaculatus sp. nov. This may possibly suggest a recent gene flow of these frogs between the Ambre and Manongarivo massifs. A comparative analysis of more co-distributed species on these massifs, as well as their habitat requirements and elevational distributions, might allow the testing of hypotheses of past rainforest connections and dispersal corridors in northern Madagascar, as well as identifying intrinsic traits favoring such dispersal in frogs and other animals.

\section{Acknowledgments}

We thank Jary H. Razafindraibe, Roger-Daniel Randrianiaina, Angeluc Razafimanantsoa, and local park guides for their help during fieldwork, and Meike Kondermann and Gabriele Keunecke for laboratory assistance with the molecular work. We are grateful for the help and research permits issued by Madagascar National Parks (MNP) and the "Direction Générale des Forêts" (DGF). This work was carried out in collaboration with the Mention Zoologie et Biodiversité Animale, Université d'Antananarivo. Field campaigns were partly supported by grants of the Volkswagen Foundation; MV and MDS were supported by grants of the Deutsche Forschungsgemeinschaft (VE247/13-1 and 15-1). RML thanks the College of Wooster for the sabbatical that allowed this project to be completed.

\section{References}

AmphibiaWeb. 2018. AmphibiaWeb: Information on Amphibian Biology and Conservation. http://amphibiaweb.org/ [accessed 4 Jul. 2018].

Andreone F. 2014. Madagascar: Risk review is under way for invasive toad. Nature 512: 253. https://doi.org/10.1038/512253c

Andreone F., Glaw F., Mattioli F., Jesu R., Schimmenti G., Randrianirina J.E. \& Vences M. 2009. The peculiar herpetofauna of some Tsaratanana rainforests and its affinities with Manongarivo and other massifs and forests of northern Madagascar. Italian Journal of Zoology 76: 92-110. https://doi.org/10.1080/11250000802088603

Bletz M.C., Scherz M.D., Rakotoarison A., Lehtinen R.M., Glaw F. \& Vences M. 2018. Stumbling upon a new frog species of Guibemantis (Anura: Mantellidae) on the top of the Marojejy massif in northern Madagascar. Copeia 106: 255-263. https://doi.org/10.1643/CH-17-655 
Blommers-Schlösser R.M.A. 1979. Biosystematics of the Malagasy frogs. I. Mantellinae (Ranidae). Beaufortia 29: 1-77.

Brown J.L., Sillero N., Glaw F., Bora P., Vieites D.R. \& Vences M. 2016. Spatial biodiversity patterns of Madagascar's amphibians and reptiles. PLOS ONE 11: e0144076.

https://doi.org/10.1371/journal.pone.0144076

Bruford M., Hanotte O., Brookfield J. \& Burke T. 1992. Single-locus and multilocus DNA fingerprint. In: A. Hoelzel (ed.) Molecular Genetic Analysis of Populations: a Practical Approach. IRL Press, Oxford: $225-270$.

Darriba D., Taboada G.L., Doallo R. \& Posada D. 2012. jModelTest 2: more models, new heuristics and parallel computing. Nature Methods 9: 772. https://doi.org/10.1038/nmeth.2109

Glaw F. \& Vences M. 2006. Phylogeny and genus-level classification of mantellid frogs (Amphibia, Anura). Organisms Diversity and Evolution 6: 236-253. https://doi.org/10.1016/j.ode.2005.12.001

Glaw F. \& Vences M. 2007. A Field Guide to the Amphibians and Reptiles of Madagascar, $3^{\text {rd }}$ ed. Vences and Glaw Verlag, Cologne.

Glaw F., Vences M. \& Gossmann, V. 2000. A new species of Mantidactylus (subgenus Guibemantis) from Madagascar, with a comparative survey of internal femoral gland structure in the genus (Amphibia: Ranidae: Mantellinae). Journal of Natural History 34: 1135-1154.

https://doi.org/10.1080/00222930050020140

Kumar S., Stecher G. \& Tamura K. 2016. MEGA7: Molecular Evolutionary Genetics Analysis version 7.0 for bigger datasets. Molecular Biology and Evolution 33: 1870-1874.

https://doi.org/10.1093/molbev/msw054

Lehtinen R.M., Nussbaum R.A., Richards C.M., Cannatella D.C. \& Vences M. 2007. Mitochondrial genes reveal cryptic diversity in plant-breeding frogs from Madagascar (Anura, Mantellidae, Guibemantis). Molecular Phylogenetics and Evolution 44: 1121-1129. https://doi.org/10.1016/j.ympev.2007.05.020

Lehtinen R.M., Glaw F. \& Vences M. 2011. Two new plant-breeding frog species (Anura: Mantellidae, Guibemantis) from southeastern Madagascar. Herpetological Journal 21: 95-112.

Lehtinen R.M., Glaw F., Andreone F., Pabijan M. \& Vences M. 2012. A new species of putatively pond breeding frog of the genus Guibemantis from Madagascar. Copeia 2012: 648-662.

https://doi.org/10.1643/CH-11-128

Perl R.G.B., Nagy Z.T., Sonet G., Glaw F., Wollenberg K.C. \& Vences M. 2014. DNA barcoding Madagascar's amphibian fauna. Amphibia-Reptilia 35: 197-206.

https://doi.org/10.1163/15685381-00002942

Rambaut A. \& Drummond A. 2007. Tracer v1 .4. [Online.] Available at http://tree.bio.ed.ac.uk. [accessed 16 Jul. 2018].

Ronquist F., Teslenko M., van der Mark P., Ayres D.L., Darling A., Höhna S., Larget B., Liu L., Suchard M.A.\& Huelsenbeck J.P. 2012. MrBayes 3.2: Efficient Bayesian phylogenetic inference and model choice across a large model space. Systematic Biology 61: 539-542. https://doi.org/10.1093/sysbio/sys029

Vences M. \& Glaw F. 2005. A new species of Mantidactylus from the east coast of Madagascar and its molecular phylogenetic relationships within the subgenus Guibemantis. Herpetological Journal 15: $37-44$.

Vences M., Köhler J., Pabijan M., Bletz M.C., Gehring P.-S., Hawlitschek O., Rakotoarison A., Ratsoavina F.M., Andreone F., Crottini A. \& Glaw F. 2017. Taxonomy and geographic distribution of 
Malagasy frogs of the Gephyromantis asper clade, with description of a new subgenus and revalidation of Gephyromantis ceratophrys. Salamandra 53: 77-98.

Vences M., Rakotoarison A., Rakotondrazafy A.M.N.A., Ratsoavina F.M., Randrianiaina R.D., Glaw F., Lehtinen R.M. \& Raxworthy C.J. 2013. Assessing the diversity of phytotelmic frogs along Madagascar's east coast: Redefinition of Guibemantis bicalcaratus (Boettger, 1913) and revalidation of Guibemantis methueni (Angel, 1929). Vertebrate Zoology 63: 193-205.

Vieites D.R., Wollenberg K.C., Andreone F., Köhler J., Glaw F. \& Vences M. 2009. Vast underestimation of Madagascar's biodiversity evidenced by an integrative amphibian inventory. Proceedings of the National Academy of Science of the USA 106: 8267-8272. https://doi.org/10.1073/pnas.0810821106

Manuscript received: 10 January 2018

Manuscript accepted: 11 June 2018

Published on: 19 July 2018

Topic editor: Rudy Jocqué

Desk editor: Pepe Fernández

Printed versions of all papers are also deposited in the libraries of the institutes that are members of the EJT consortium: Muséum national d'Histoire naturelle, Paris, France; Botanic Garden Meise, Belgium; Royal Museum for Central Africa, Tervuren, Belgium; Natural History Museum, London, United Kingdom; Royal Belgian Institute of Natural Sciences, Brussels, Belgium; Natural History Museum of Denmark, Copenhagen, Denmark; Naturalis Biodiversity Center, Leiden, the Netherlands; Museo Nacional de Ciencias Naturales-CSIC, Madrid, Spain; Real Jardín Botánico de Madrid CSIC, Spain; Zoological Research Museum Alexander Koenig, Bonn, Germany. 